A N N A L E S

UNIVERSITATIS MARIAE CURIE-SKŁODOWSKA

LUBLIN - POLONIA

VOL. LXIII, 2

SECTIO G

2016

Uniwersytet Marii Curie-Skłodowskiej w Lublinie

adam.szot@poczta.umcs.lublin.pl

\title{
ADAM SZOT
}

\section{Klauzula generalna jako ponadgałęziowa konstrukcja systemu prawa}

General Clause as a Multi-brach Legal System Construction

\section{WPROWADZENIE}

Pojęcie klauzuli generalnej nie zostało zdefiniowane w języku prawnym. W doktrynie natomiast występują różnorodne koncepcje dotyczące zarówno istoty, zakresu ujęcia, jak i jej stosowania, czego najdobitniej dowodzą rozważania prowadzone we wcześniejszych częściach niniejszej monografii w odniesieniu do dorobku naukowego i praktycznego poszczególnych gałęzi prawa.

Samo pojęcie i charakter klauzul generalnych jest przedmiotem licznych sporów na gruncie rodzimej teorii prawa ${ }^{1}$. W mniejszym zakresie rozważania na ten temat podejmują przedstawiciele szczegółowych nauk prawnych ${ }^{2}$ oraz praktyka

1 Dla przykładu warto wskazać na prace: J. Wróblewski, Przepisy odsyłajace, „Zeszyty Naukowe Uniwersytetu Łódzkiego" 1964, z. 35, s. 3-22; A. Stelmachowski, Klauzule generalne w prawie cywilnym, „Państwo i Prawo” 1965, z. 1, s. 5-20; J. Czarzasty, Przyczynek do problematyki klauzul generalnych, „Państwo i Prawo” 1978, z. 5, s. 83-92; J. Nowacki, Problem blankietowości przepisów zawierających klauzule generalne, [w:] Prawo w zmieniającym się społeczeństwie. Księga jubileuszowa Profesor Marii Boruckiej-Arctowej, red. G. Skąpska, J. Czapska, K. Daniel, K. Pałecki, Kraków 1992; L. Leszczyński, Tworzenie generalnych klauzul odsytajacych, Lublin 2000; S. Wronkowska, Z. Ziembiński, Zarys teorii prawa, Poznań 2001, s. 223-226; L. Leszczyński, Stosowanie generalnych klauzul odsyłających, Kraków 2001, passim.

2 Zob. między innymi: Z. Radwański, M. Zieliński, Klauzule generalne w prawie prywatnym, [w:] System Prawa Prywatnego, t. 1: Prawo cywilne - część ogólna, red. M. Safjan, Warszawa 2007, s. 335 i n.; A. Choduń, A. Gomułowicz, A. Skoczylas, Klauzule generalne i zwroty niedookreślone $w$ prawie podatkowym $i$ administracyjnym. Wybrane zagadnienia teoretyczne $i$ orzecznicze, Warszawa 2013, s. 26; T. Zieliński, Klauzule generalne w nowym porządku konstytucyjnym, „Pań- 
prawnicza. Jest to $\mathrm{w}$ naturalny sposób podyktowane istotą i charakterem teorii prawa jako nauki ogólnej, której cel to dostarczenie - zgodnie z postulatem wewnętrznej integracji prawoznawstwa ${ }^{3}$ - odpowiedniego ,instrumentarium” metodologiczno-terminologicznego dla poszczególnych dogmatyk prawniczych oraz stworzenie podwalin dla praktyki prawniczej. Tak sformułowane twierdzenia o ogólnym charakterze są następnie adaptowane i uszczegóławiane na poziomie poszczególnych gałęzi (dogmatyk prawniczych).

W związku z faktem, że ani przedmiotem, ani celem niniejszej części publikacji nie jest próba prowadzenia rozważań natury ontologicznej czy też naukowa refleksja na temat istoty ogólnych nauk prawnych, pominięte zostaną zagadnienia poddane wnikliwym analizom we wcześniejszych częściach pracy, odnoszące się do istoty klauzul generalnych w ogólności i stosowania szczegółowych klauzul na gruncie poszczególnych gałęzi prawa, oraz zagadnienia, które z punktu widzenia intencji autora stanowią tło do prowadzenia dalszych rozważań.

Celem, który przyświeca autorowi, jest chęć wyciągnięcia przed nawias pewnych ogólnych rozważań, pozwalających patrzeć na klauzulę generalną jako na pewną uniwersalną konstrukcję prawną. Główną hipotezą jest założenie, że ponadgałęziowy charakter klauzul generalnych przejawia się w tym, że konstrukcje tego typu występują w poszczególnych działach prawa, jak również cechuje się wieloma innymi podobieństwami, które przełamują tradycyjny (aczkolwiek dyskusyjny) podział gałęziowy systemu prawa.

\section{KLAUZULE GENERALNE I ICH ADRESACI}

Pierwszym dostrzeżonym podobieństwem jest samo postrzeganie przez przedstawicieli szczegółowych nauk prawnych generalnej klauzuli odsyłającej jako konstrukcji normatywnej, zawartej w obowiązującym przepisie prawnym, która obliguje ,Zwykłe” podmioty prawa (adresatów pierwotnych) lub organy stosujące prawo do sięgnięcia do pewnych kryteriów, wartości, zasad, ocen, które nie są expressis verbis ,zawarte” w przepisie, ale mają charakter pozaprawny. Sięgnięcie to jest konieczne, aby zrekonstruować „pełną” normę prawną, z której podmioty te czerpią informacje na temat swoich praw i obowiązków lub która stanowi podstawę ustalenia konsekwencji prawnych w procesie formułowania władczych decyzji jednostkowych przez kompetentne organy władzy publicznej. W tym też sensie klauzula generalna, jak wskazują L. Leszczyński i G. Maroń, jest sposobem „komunikowania się” prawodawcy z adresatami norm prawnych

stwo i Prawo" 1997, z. 11-12, s. 134; A. Wypych-Żywicka, [w:] Zarys systemu prawa pracy, t. 1: Część ogólna prawa pracy, red. K.W. Baran, Warszawa 2010, s. 766.

3 Szerzej między innymi: K. Opałek, Problemy ,wewnętrznej” $i$,zewnętrznej” integracji nauk prawnych, „Krakowskie Studia Prawnicze” 1968, nr 1-2, s. 10. 
co do uwzględnienia kryteriów pozaprawnych w decyzjach stosowania prawa czy w zachowaniach ,przestrzegania” prawa ${ }^{4}$.

Tak rozumiana klauzula generalna występuje i ma zastosowanie, po pierwsze, w kształtowaniu stosunków prawnych w życiu codziennym jednostek, a po drugie $-\mathrm{w}$ ich interakcjach $\mathrm{w}$ ramach określonych struktur organizacyjnych. W drugim przypadku chodzi o występowanie lub stosowanie odesłań pozaprawnych w odniesieniu do wewnętrznych stosunków, np. w ramach samorządów zawodowych czy spółek prawa handlowego. Oczywiście należy mieć na względzie fakt, że o ile obowiązywanie lub stosowanie generalnych klauzul odsyłających w wewnętrznych regulacjach prawnych organizacji skupiających obywateli jest możliwe i dopuszczalne, z uwagi na niejako dobrowolność przynależności do danej struktury, o tyle (w państwie prawa) nie jest możliwe, aby tego typu odesłania stanowiły podstawę jakichkolwiek stosunków prawnych, w szczególności o władczym (administracyjnym czy karnoprawnym) charakterze, względem podmiotów nieprzynależących do danej struktury.

Warto również wskazać, iż klauzule generalne występujące w prawie międzynarodowym, $\mathrm{w}$ tym $\mathrm{w}$ zakresie ochrony praw człowieka, są adresowane nie tylko do „zwykłych” podmiotów prawa czy organów stosujących prawo, ale także (a niejednokrotnie przede wszystkim) do prawodawcy krajowego. W odniesieniu do regulacji Europejskiej Konwencji Praw Człowieka dają one możliwość ograniczenia lub uszczegółowienia praw człowieka do specyfiki warunków lokalnych, wykorzystując w tym celu pozaprawne wartości, na które kierunkuje go Konwencja Europejska.

\section{AKSJOLOGICZNE UWIKŁANIE KLAUZUL GENERALNYCH}

Kolejnym dostrzegalnym podobieństwem między poszczególnymi gałęziami prawa, na które wskazują bezpośrednio lub pośrednio przedstawiciele szczegółowych nauk prawnych, są aksjologiczne konotacje klauzul generalnych. Powiązań tych można poszukiwać w co najmniej trzech obszarach.

Pierwszym z nich, chyba najbardziej oczywistym, jest obszar aksjologii zewnętrznej (pozasystemowej) jako aksjologii, do której odsyła konkretna klauzula generalna. Odniesienie do pewnych wartości, ocen, norm (niezależnie od tego, czy są to wartości moralne, ekonomiczne czy polityczne) otwiera system prawny na aksjologię, którą prawodawca uznał za cenną (wartościową). Stanowi ona podstawę formułowania ocen. Oceny takie muszą natomiast odwoływać się do

4 Szerzej: L. Leszczyński, G. Maroń, Pojęcie i treść zasad prawa i generalnych klauzul odsyłajacych. Uwagi porównawcze, „Annales UMCS. Sectio G” 2013, Vol. 60, nr 1, s. 82 i n.; A. Kalisz, Mediacja jako forma dialogu w stosowaniu prawa, Warszawa 2016, s. 86-88. 
oficjalnie przyjmowanego i akceptowanego systemu wartości ${ }^{5}$. W idealizacyjnym założeniu, w demokratycznym państwie prawa, jest to odzwierciedleniem preferencji społecznych. Otwarcie systemu prawnego następuje również w odniesieniu do tych klauzul generalnych, które odwołują się do obyczajów, mimo że one same nie mają uzasadnienia aksjologicznego, lecz uzasadnienie faktualne (faktyczne).

Drugim obszarem jest obszar współwystępowania aksjologii systemowej (wyrażonej między innymi w zasadach prawa) i pozasystemowej, do której odsyłają klauzule generalne, a tym samym współtworzenia aksjologii porządku prawnego. W założeniu wartości wyrażone przez zasady prawa i te, do których odnosi się klauzula, powinny wzajemnie się dopełniać i przenikać. Należy jednak mieć na względzie, iż czasami mogą one pozostawać względem siebie w relacji częściowej lub całkowitej sprzeczności. Może to nastąpić w szczególności w sytuacji głębokiej zmiany społecznej, zwłaszcza w początkowym jej etapie, kiedy system prawny „nie nadąża” za zmianami życia społeczno-gospodarczego, w tym wartości, które leżą u jego podstaw.

Trzecim obszarem jest sytuacja, w której aksjologia systemowa i pozasystemowa tworzą jedność. Sytuacja taka następuje w przypadku, gdy zasady prawa zawierają w swej treści generalną klauzulę odsyłającą (np. art. 7 k.p.a. czy art. 5 k.c.) $)^{6}$.

\section{ELASTYCZNOŚĆ PRAWA I JEGO STOSOWANIA}

Trzecią cechą wspólną wszystkich gałęzi prawa jest cel i skutek wprowadzenia klauzul generalnych, tj. uelastycznienie prawa oraz procesów jego stosowania. Posługując się tą konstrukcją, prawodawca daje interpretatorowi możliwość przełamania statyki przepisów prawnych przez korektę znaczeniową argumentów stricte jurydycznych dzięki sięgnięciu do zmiennego aksjologicznie otoczenia prawnego ${ }^{7}$. Tym samym tworzy to możliwość prowadzenia procesów wykładni i stosowania prawa w sposób dynamiczny, pozwalający na dostosowanie treści decyzji prawnych (w tym decyzji stosowania prawa) do aktualnych potrzeb i uwarunkowań w dynamicznie zmieniającym się otoczeniu społeczno-gospodarczym. Daje to szansę uwzględnienia w indywidualnych sytuacjach tego, co „nieuchwytne" dla prawodawcy.

5 Z. Ziembiński, Teoria prawa, Warszawa - Poznań 1973, s. 131.

6 Rozważania na ten temat zawarte są między innymi w: M. Zdyb, Interes jednostki a interes publiczny (społeczny). Konflikt interesów, „Annales UMCS. Sectio G” 1993, Vol. 40, s. 307. Zob. też: idem, Interes publiczny w orzecznictwie Trybunału Konstytucyjnego, [w:] Pojęcie interesu w naukach prawnych, prawie stanowionym i orzecznictwie sądowym Polski i Ukrainy, red. A. Korybski, M.W. Kostyckij, L. Leszczyński, Lublin 2006, s. 205 i n.

7 Zob. między innymi: T. Zieliński, Klauzule generalne $w$ procesie karnym, [w:] Zasady procesu karnego wobec wyzwań współczesności. Księga ku czci Profesora Stanisława Waltosia, red. J. Czapska, A. Gaberle, A. Światłowski, A. Zoll, Warszawa 2000, s. 786. 
Klauzule generalne (podobnie jak inne zwroty niedookreślone) mogą wprawdzie wywoływać pewne niebezpieczeństwa związane z relatywizmem postrzegania wartości ${ }^{8}$, do których odsyłają, ale zarazem nadają normom prawnym bardziej elastycznego charakteru i sprawiają, że stają się one bardziej „wrażliwe na otaczającą rzeczywistość"

Elastyczność prawa i jego stosowania, w związku z występowaniem generalnych klauzul odsyłających, może być postrzegana również z perspektywy historycznej ewolucji państwa i zmian społecznych, w tym zmian aksjologii społecznej. W tym sensie występowanie klauzuli generalnej w przepisie prawnym pozwala na zmianę treściową rekonstruowanej z niego normy prawnej w zmieniających się warunkach zewnętrznych i wewnętrznych (ustrojowych).

Wspomniana elastyczność pozwala nie tylko na dostosowanie treści podejmowanych decyzji do indywidualnego stanu faktycznego sprawy przy uwzględnieniu złożonych i dynamicznie zmieniających się uwarunkowań, ale także niejednokrotnie może w ogóle pozwolić na podjęcie jakiejkolwiek decyzji, przełamując ewentualny impas związany z niedostosowaniem obowiązujących regulacji prawnych do otoczenia, w jakim są one stosowane. Hipotetyczny całkowity brak klauzul generalnych w systemie prawa mógłby bowiem prowadzić do niemocy decyzyjnej. W konsekwencji prawodawca, nie mogąc posługiwać się tą konstrukcją, tworzyłby coraz bardziej kazuistyczne regulacje prawne, chcąc unormować jak największą liczbę przyszłych, potencjalnych sytuacji.

Elastyczność prawa i jego stosowania wiąże się bezpośrednio ze zmiennością treściową (znaczeniową) generalnych klauzul odsyłających. Prawodawca, posługując się tą konstrukcją, odwołuje się do pewnego dynamicznego zespołu wartości, ocen, norm. Nawet w przypadku odwołania się do norm zwyczajowych, które ze swej natury wiążą się z dłuższą praktyką postępowania w określony sposób, zmienność ta może być obserwowana. Jak podkreślano we wcześniejszych częściach artykułu, niektóre z istniejących obecnie w systemie prawa klauzul generalnych mają swoją, niejednokrotnie długą, genezę i mimo że powstawały w innych warunkach historycznych rozwoju państwa, to obowiązują do dzisiaj i są z powodzeniem stosowane (np. klauzula „nieuzasadnionego wypowiedzenia umowy o pracę” z k.p. czy klauzula „interesu publicznego” z k.p.a. oraz innych ustaw szczegółowych, klauzula „zasad współżycia społecznego” z k.c.).

8 Zob. między innymi: Z. Radwański, Czy klauzula generalna społeczno-gospodarczego przeznaczenia prawa powinna określać treść prawa własności, [w:] ARS ET USUS. Księa pamiątkowa ku czci Sędziego Stanistawa Rudnickiego, Warszawa 2005, s. 230; A. Pomorska, Kontrowersje wokót przesłanek umorzenia zaległości podatkowych, [w:] Ex iniuria non oritur ius. Księga ku czci Profesora Wojciecha Łączkowskiego, red. A. Gomułowicz, J. Małecki, Poznań 2003, s. 276.

9 M. Zdyb, J. Stelmasiak, Zasady ogólne Kodeksu postępowania administracyjnego. Orzecznictwo Naczelnego Sądu Administracyjnego z komentarzem, Lublin 1992, s. 47. 
Ponadto warto wskazać, iż w odniesieniu do klauzul generalnych, które w warstwie semantycznej „przeżyły” zmianę ustrojową w Polsce po 1989 r., dostrzegalna jest wręcz rewolucyjna, a nie tylko ewolucyjna (związana z ciągle postępującymi powolnymi procesami zmian aksjologii społeczeństw), ich redefinicja $\mathrm{w}$ sensie esencjonalnym ${ }^{10}$. Tym samym jeszcze mocniej potwierdza to tezę o uelastycznieniu prawa i procesów jego stosowania dzięki konstrukcji generalnej klauzuli odsyłającej, niezależnie od jej usytuowania w systemie prawa.

\section{ROLA PRAKTYKI STOSOWANIA PRAWA}

Analiza rozważań prowadzonych w ramach szczegółowych nauk prawnych wskazuje jednoznacznie na wspólną dla wszystkich gałęzi prawa zależność, a raczej dwie zależności:

- ustalenia treści/zawartości generalnej klauzuli odsyłającej należy dokonywać w odniesieniu do konkretnego stanu faktycznego,

- władczego ustalenia treści/zawartości generalnej klauzuli odsyłającej będzie zawsze dokonywał podmiot stosujący prawo (niezależnie od typu stosowania prawa).

W odniesieniu do drugiej z tych zależności należy poczynić krótki komentarz. Tak jak wskazano wcześniej, prawodawca korzysta z konstrukcji klauzul generalnych, komunikując się z różnymi rodzajami adresatów. W tym sensie niektóre z klauzul są skierowane w pierwszej kolejności do „zwykłych” podmiotów prawa, a inne do organów stosujących prawo. Niezależnie od tego, że adresatem pierwotnym klauzuli (normy zakodowanej w przepisie zawierającym klauzulę) jest ,zwykły" podmiot prawa ${ }^{11}$, władczego ustalenia jej treści zawsze dokona organ stosujący prawo. Innymi słowy, jeśli dojdzie to sytuacji, w której zostanie zainicjowany proces decyzyjny zmierzający do wydania władczej decyzji jednostkowej, to ostatecznego ustalenia treści klauzuli dokona decydent i to ta treść będzie „właściwym” rozumieniem wartości, do których klauzula generalna odsyła niezależnie, iż może ona nie być tożsama z treścią ustaloną przez adresata pierwotnego.

Zawartość treściowa konkretnej klauzuli generalnej podlega każdorazowemu ustaleniu w procesie stosowania prawa. Oznacza to, iż jest ona

10 Zob. M. Gersdorf, Podstawowe dylematy zwiazane z prawem pracy w okresie transformacji ustrojowej, „Praca i Zabezpieczenie Społeczne” 2003, nr 5, s. 3. Zob. A. Rycak, Powszechna ochrona trwatości stosunku pracy, Warszawa 2013, s. 333; M. Latos-Miłkowska, Ksztatt powszechnej ochrony przed wypowiedzeniem we wspótczesnym prawie pracy, „Praca i Zabezpieczenie Społeczne" 2008, nr 10, s. 11.

11 Na przykład czasami normy prawne, określając wymogi stawiane do pełnienia określonych funkcji, dysponowania określonym prawem, posiadania określonych uprawnień, posługują się generalnymi klauzulami odsyłającymi, jak ma to miejsce między innymi w odniesieniu do wymogu posiadania „nieskazitelnego charakteru”. 
przedmiotem rozumowań prowadzonych przez sądy i organy administracji publicznej różnych instancji, które niezależnie od swojego miejsca w strukturze ustrojowej lub procesowej dokonują każdorazowego ustalenia treści klauzuli ${ }^{12}$.

Obowiązek każdorazowego ustalenia treści klauzuli wiąże się nie tylko z konstrukcjami odnoszącymi się do cech specyficznych konkretnego stanu faktycznego (np. „dobro dziecka”, „interes jednostki”), ale także do klauzul o charakterze systemowym (np. ,interes publiczny”, „moralność publiczna”, „,dobro wymiaru sprawiedliwości").

$\mathrm{W}$ doktrynie i orzecznictwie w przeszłości były podejmowane nieliczne próby „definiowania” in abstracto systemowych klauzul generalnych. Przykładem może być dążenie do określenia rozumienia konstrukcji ,interesu publicznego" w wyroku SN z dnia 31 maja 1933 r. ${ }^{13}$ czy „,nieskazitelnego charakteru” w wyroku NSA z dnia 18 listopada 1999 r. ${ }^{14}$ Obecnie takie próby zostały zarzucone na rzecz „definiowania” klauzul in concreto. Jednocześnie wydawać by się mogło, iż z uwagi na rolę podmiotów stosujących prawo w procesie ustalania treści odesłań decydenci (sądy, organy administracji publicznej) będą podejmowali próbę wskazania konkretnych wartości, które kryją się pod daną klauzulą. Idąc dalej, można byłoby postawić tezę o swoistej uniwersalizacji wartości przez procesy decyzyjne. Jeśli bowiem przyjąć, iż upoważnione organy - dokonując kontroli decyzji, których elementem normatywnej podstawy jest generalna klauzula odsyłająca - wpływają na ich rozumienie przez organy niższych instancji, to oddziałują również (przynajmniej pośrednio) na treść przyszłych decyzji stosowania prawa. Założenie to jednak nie znajduje potwierdzenia (przynajmniej dostatecznego) w rzeczywistości ${ }^{15}$. Najczęściej praktyka stosowania prawa zmierza w kierunku albo ogólnego powoływania w uzasadnieniu decyzji konkretnej klauzuli, po którą decydent był zobowiązany sięgnąć bez bliższego określania, jak organ (sąd, organ administracji) ją rozumiał, albo do egzemplifikacyjnego jej (najczęściej w kontekście konkretnego stanu faktycznego) określenia ${ }^{16}$.

12 Szerzej między innymi: M. Wyrzykowski, Pojęcie interesu społecznego w prawie administracyjnym, Warszawa 1986, s. 127.

13 „»Interesem« jest bądź istniejące, bądź przyszłe dobro materialne lub osobiste lub dobro idealne, związane z organizacją życia zbiorowego i prawidłowością jej funkcjonowania. »Publicznym « jest interes zbiorowy organizacji społecznej, państwa lub samorządu, albo w ogóle życia społecznego" - zob. wyrok SN z dnia 31 maja 1933 r., II K 285/33, OSN(K) 1933, z. 8, poz. 157.

14 Wyrok NSA z dnia 18 listopada 1999 r., II SA 1131/99, LEX nr 46696.

15 Szerzej zob. A. Kalisz, A. Szot, (Przewrotna) rola klauzul generalnych w orzecznictwie europejskim. Studium , interesu publicznego” $i$, moralności publicznej”, [w:] Konwergencja czy dywergencja kultur i systemów prawnych?, red. O. Nawrot, S. Sykuna, J. Zajadło, Warszawa 2012, s. 213-220.

16 Zob. między innymi: wyrok NSA z dnia 22 kwietnia 1999 r., SA/Sz 850/98, LEX nr 36843; wyrok WSA w Lublinie z dnia 15 marca 2013 r., I SA/Lu 612/12; wyrok NSA z dnia 5 kwietnia 2001 r., II SA 725/00, LEX nr 53476. 
Nie oznacza to braku wpływu orzeczeń (szczególnie „najwyższych” instancji sądowniczych) na praktykę rozumienia i posługiwania się konkretnymi klauzulami generalnymi. $Z$ racji swojego autorytetu i rangi wyznaczają one pewne kierunki w tym zakresie. Dla przykładu warto wskazać na ewolucję sposobu postrzegania i określania wzajemnych relacji klauzul ,interesu społecznego” i ,słusznego interesu obywateli" na gruncie art. 7 k.p.a. ${ }^{17}$

Generalne klauzule odsyłające są narzędziem świadomego kreowania przez prawodawcę luzów decyzyjnych w procesach stosowania prawa. Ich stosowanie nie oznacza jednak dowolności decydenta. Musi on dokonywać ustalenia ich treści w kontekście konkretnego stanu faktycznego sprawy, przy uwzględnieniu reguł i zasad systemu prawnego ${ }^{18}$ oraz całokształtu wartości społecznych (pozaprawnych). Odwołanie się przez konstrukcję klauzuli generalnej do pewnych wartości, norm i ocen znajdujących się poza systemem prawa nie oznacza przyznania organowi stosującemu prawo niczym nieograniczonej możliwości „kształtowania” ich treści, szczególnie w zderzeniu $\mathrm{z}$ pewnymi wartościami utrwalonymi $\mathrm{w}$ demokratycznym państwie prawa.

\section{GENERALNE KLAUZULE ODSYŁAJĄCE A LUZY DECYZYJNE}

Konstrukcja generalnej klauzuli odsyłającej jest - niezależnie od przedmiotu regulacji czy gałęzi prawa, w której występuje - elementem polityki tworzenia prawa i świadomego kreowania luzu decyzyjnego, która w praktyce ma umożliwić przełamanie statyki regulacji prawnych i dostosowanie treści indywidualnej decyzji stosowania prawa do jednostkowych cech stanu faktycznego, przy uwzględnieniu zmieniających się uwarunkowań społeczno-gospodarczych. Tym samym jej występowanie $\mathrm{w}$ przepisie prawnym, stanowiącym źródło normatywnej podstawy projektowanej decyzji, wzmacnia wartość elastyczności prawa i jego stosowania. Intuicyjnie jednak może się wydawać, że w praktyce występowanie generalnej klauzuli odsyłającej będzie osłabiało pewność prawa, a przez to

17 Szerzej: M. Wyrzykowski, op. cit., s. 52; W. Jakimowicz, Wyktadnia w prawie administracyjnym, Kraków 2006, s. 124-125; M. Zdyb, Prawny interes jednostki w sferze materialnego prawa administracyjnego. Studium teoretycznoprawne, Lublin 1991, s. 201-209; A.S. Duda, Interes prawny w polskim prawie administracyjnym, Warszawa 2008, s. 19-26 i przywołana tam literatura; W. Szwajdler, Ochrona prawna interesu indywidualnego w prawie budowlanym, Toruń 1993, s. 26-29; A. Żurawik, , Interes publiczny”, ,, interes społeczny” $i$,, interes społecznie uzasadniony”, ,Ruch Prawniczy, Ekonomiczny i Socjologiczny" 2003, nr 2, s. 60-62 i przywołana tam literatura; wyrok WSA w Gliwicach z dnia 7 lutego 2013 r., IV SA/Gl 211/12, LEX nr 1278056; wyrok NSA z dnia 26 lipca 2006 r., II OSK 1004/05, LEX nr 266429; wyrok NSA w Warszawie z dnia 24 maja 1999 r., II SA 547/99, LEX nr 46292; wyrok NSA z dnia 7 grudnia 2011 r., I OSK 4/11, LEX nr 1149372; wyrok NSA w Warszawie z dnia 11 czerwca 1981 r., SA 820/81, LEX nr 9626; wyrok SN z dnia 18 listopada 1993 r., III ARN 49/93, LEX nr 9595; wyrok TK z dnia 20 marca 2006 r., K 17/05, LEX nr 182494.

18 Zob. Z. Janowicz, Kodeks postępowania administracyjnego. Komentarz, Warszawa 1999, s. 602 . 
poczucie bezpieczeństwa jednostki. Jeśli bowiem organ dokonuje każdorazowego ustalenia treści odesłania, to w różnych sprawach o zbliżonym stanie faktycznym może on dojść do innego wniosku co do danej treści, tym bardziej jeśli weźmiemy pod uwagę mnogość i różnorodność podmiotów stosujących prawo w państwie. Tym samym, jeśli w analogicznych stanach faktycznych zapadają różne rozstrzygnięcia, można postawić również hipotezę, iż występowanie klauzul generalnych może prowadzić do naruszenia jednolitości stosowania prawa.

$\mathrm{Na}$ to zagadnienie warto spojrzeć także $\mathrm{z}$ innego punktu widzenia - jeśli organ dokonuje każdorazowego ustalenia treści odesłania i dokonuje kwalifikacji określonych elementów stanu faktycznego z jego uwzględnieniem w procesie formułowania decyzji finalnej, to treść tej decyzji będzie w większym stopniu dopasowana do danego przypadku, dzięki czemu będzie wzmacniać poczucie pewności prawa i jego stosowania. Chodzi o pewność subiektywnie postrzeganą przez adresata decyzji jako pewność, iż rozstrzygnięcie w pełni odpowiada indywidualnym cechom danej sprawy.

Fakt występowania klauzuli generalnej aktualizuje obowiązek sięgnięcia do określonych pozaprawnych systemów wartości i oceny. W tym zakresie podmiot stosujący prawo nie dysponuje żadnym zakresem uznaniowości, natomiast jest ona szczególnie widoczna w odniesieniu do ustalania „treści” odesłania, czyli ustalenia, które wartości lub oceny kryją się pod daną klauzulą i luzem w kontekście sposobu ich włączenia i roli $w$ rozumowaniach podejmowanych $w$ procesach decyzyjnych (w tym związanych $z$ ustaleniem treści decyzji finalnej).

Jednocześnie, jak już wskazywano, luz decyzyjny kreowany przez klauzule generalne nie jest nieograniczony, a organ stosujący prawo nie ma dowolności w ustalaniu znaczenia odesłania. Należy również dodać, iż występowanie w systemie prawnym klauzuli generalnej jako źródła swobody decyzyjnej podmiotu stosującego prawo wpływa jednocześnie na ukierunkowanie lub ograniczenie tej swobody wynikającej z innych źródeł (świadomie lub nieświadomie kreowanych przez prawodawcę). W tym sensie np. odesłania z art. 7 k.p.a. ukierunkowują rozumowania organu administracji podejmującego decyzje w ramach uznania administracyjnego. Oznacza to, że dyskrecjonalna władza administracji, przejawiająca się w możliwości wyboru jednego spośród prawnie dopuszczalnych rozstrzygnięć $\mathrm{w}$ ramach uznania administracyjnego, zostaje ukierunkowana przez konieczność dokonania ustalenia treści obu zawartych w tym przepisie klauzul oraz ich ważenia w kontekście konkretnego stanu faktycznego. Tym samym staje się dyrektywą wyboru konsekwencji ${ }^{19}$. Oznacza to,

19 Zob. szerzej: J. Wróblewski, Sądowe stosowanie prawa, Warszawa 1988, s. 246; M. Jaśkowska, Uznanie administracyjne a inne formy władzy dyskrecjonalnej administracji publicznej, [w:] System Prawa Administracyjnego, t. 1: Instytucje prawa administracyjnego, red. R. Hauser, Z. Niewiadomski, A. Wróbel, Warszawa 2010, s. 263; L. Leszczyński, Stosowanie generalnych 
iż występowanie w systemie prawa generalnej klauzuli odsyłającej tworzy określony zakres luzu decyzyjnego samo przez się, a jednocześnie ogranicza zakres luzu generowanego przez inne czynniki.

\section{NIEKONSEKWENCJA TERMINOLOGICZNA PRAWODAWCY}

Przedstawiciele nauk dogmatycznoprawnych wskazują jednoznacznie na pozytywne aspekty korzystania przez prawodawcę z konstrukcji generalnej klauzuli odsyłającej i ich roli w procesie stosowania prawa. Podkreślane są jednak również ujemne konsekwencje występowania w systemie prawa tego typu odesłań. Poza wspomnianym już niebezpieczeństwem zachwiania równowagi między elastycznością i jednolitością stosowania prawa, a w konsekwencji pewnością prawa, należy zwrócić uwagę między innymi na problem związany z niekonsekwencją terminologiczną ustawodawcy w posługiwaniu się klauzulami. Nawet sprawny interpretator często styka się $\mathrm{w}$ praktyce $\mathrm{z}$ niemałym problemem związanym ze stosowaniem podobnie brzmiących klauzul generalnych.

Przyjęcie założenia o racjonalności prawodawcy, w szczególności w kontekście semantycznym, powoduje konieczność uznania różnego znaczenia zbliżonych do siebie, w sensie językowego wyrażenia w przepisie prawnym, klauzul generalnych. Takie sytuacje zdarzają się bardzo często (np. „,dobro dziecka” a „,interes dziecka”, a „dobro rodziny”), ale równie często spotykane są przypadki, w których doktryna i praktyka prawnicza dokonują pewnej ,korekty” prawodawcy ${ }^{20}$. Jako przykład może tu posłużyć utożsamianie ,interesu publicznego" i ,interesu społecznego” przez odwołanie się do zasad i wartości demokratycznego państwa prawa, w którym „nie ma sytuacji absolutnego utożsamiania obywatela i sfery jego indywidualnych interesów z państwem, a jedynie istnieje kwestia usankcjonowania ustawowych uprawnień i obowiązków obywatela wobec państwa oraz państwa w stosunku do obywatela"21. Dodatkowo w orzecznictwie sądowym pojęcie interesu publicznego jest utożsamiane z „,dobrem publicznym”, ,interesem zbiorowości” czy „,interesem ogólnym”22.

klauzul..., s. 21. Orzecznictwo akceptuje pogląd, iż dyrektywy wyboru konsekwencji mogą wynikać z zasad ogólnych k.p.a. - por. między innymi: wyrok NSA z dnia 19 czerwca 2013 r., II GSK 319/12, CBOSA; wyrok WSA w Warszawie z dnia 17 czerwca 2013 r., VI SA/Wa 959/13, CBOSA; wyrok WSA w Warszawie z dnia 25 czerwca 2012 r., VI SA/Wa 268/12, CBOSA.

20 Zob. T. Justyński, Nadużycie prawa w polskim prawie cywilnym, Kraków 2000, s. 98.

21 A.S. Duda, op. cit., s. 24-25. Podobnie między innymi: A. Wróbel, Interes publiczny w postępowaniu administracyjnym, [w:] Administracja publiczna u progu XXI wieku. Prace dedykowane Prof. dr. hab. Janowi Szreniawskiemu z okazji jubileuszu 45-lecia pracy naukowej, red. Z. Niewiadomski, Przemyśl 2000, passim.

22 H. Izdebski, M. Kulesza, Administracja publiczna - zagadnienia ogólne, Warszawa 2004, s. 96-97. Autorzy utożsamiają pojęcie interesu publicznego z przedmiotem działalności administracji publicznej, wskazując, iż pojęcie to jest tożsame z „dobrem wspólnym”. 
Próby korekty językowej prawodawcy są uzasadniane przeważnie koniecznością wynikającą ze spójności aksjologicznej systemu prawa oraz jego otoczenia i wzajemnego przenikania się wartości wewnątrz- i zewnątrzsystemowych. Tak czyni między innymi A. Żurawik w odniesieniu do klauzuli ,interesu publicznego”, pisząc, że „związki pomiędzy prawem a życiem społecznym są szerokie [...]. Prawo, w szczególności publiczne, jest wynikiem realizacji określonej polityki, ale również nośnikiem i odzwierciedleniem ważnych społecznie wartości. To zaś wywołuje potrzebę analizy i odkrywania normatywnej zawartości przywołanej klauzuli oraz klauzul podobnych"23.

W kontekście tych rozważań można postawić tezę, iż nie „nazwa” klauzuli ma pierwszorzędne znaczenie, lecz (co w oczywisty sposób wiąże się z istotą tej konstrukcji prawnej) jej treść i charakter. Należy jednak podkreślić, iż analizy semantycznej nie wolno pomijać i automatycznie rozszerzać treści klauzuli lub zawężać ją, lub też utożsamiać ją mechanicznie z innymi odesłaniami występującymi w systemie prawa. Każdorazowo powinno to być poprzedzone rozumowaniami organu stosującego prawo co do jej znaczenia. W związku z tym bardzo płynne pozostają granice, $w$ których doktryna i praktyka stosowania prawa mogą podejmować próby korygowania niedoskonałości językowej prawodawcy.

\section{UWAGI KOŃCOWE}

Zebrane i uporządkowane powyżej rozważania, prowadzone zarówno w odniesieniu do dorobku teorii prawa, jak i nauk dogmatycznoprawnych, jednoznacznie wskazują na to, że generalna klauzula odsyłająca jest konstrukcją przełamującą podział gałęziowy systemu prawa ze wszystkimi (tj. pozytywnymi i negatywnymi) tego konsekwencjami.

Jej występowanie w systemie prawa $\mathrm{z}$ jednej strony uelastycznia prawo i procesy jego stosowania, a $\mathrm{z}$ drugiej powoduje ciągłe napięcie na granicy tej elastyczności z pewnością i jednolitością. Powoduje to konieczność każdorazowego poszukiwania ,złotego środka”, co w praktyce nie jest zadaniem prostym i oczywistym, ponieważ na proces stosowania prawa i na samego decydenta oddziałuje szereg czynników o zróżnicowanym charakterze. W skrajnych sytuacjach sztywne dążenie do realizacji jednej ze wspomnianych wartości może prowadzić do naruszenia aksjologii systemu prawnego, a w konsekwencji do wydania decyzji błędnej (w zależności od kryterium oceny np. niezgodnej z prawem, niesprawiedliwej, nieefektywnej). W tym kontekście niezwykle ważną rolę odgrywają podmioty dokonujące weryfikacji (kontroli) poprawności przebiegu procesu decyzyjnego oraz jego efektu końcowego w postaci decyzji stosowania prawa.

${ }^{23}$ A. Żurawik, op. cit., s. 57. 
Odpowiedzialna i dojrzała praktyka prawnicza i nauka prawa są w stanie stworzyć odpowiednie konstrukcje teoretyczne i narzędzia oraz mechanizmy praktyczne czyniące poszukiwanie wspomnianego „złotego środka” łatwiejszym i pewniejszym. Jednocześnie jego odnalezienie nie jest w pełni możliwe z uwagi na zmiany w otaczającym nas świecie i konieczność nadążania za nimi oraz stałego zderzania się statyki regulacji prawnych i dynamiki życia.

\section{BIBLIOGRAFIA}

Choduń A., Gomułowicz A., Skoczylas A., Klauzule generalne i zwroty niedookreślone w prawie podatkowym i administracyjnym. Wybrane zagadnienia teoretyczne i orzecznicze, Warszawa 2013.

Czarzasty, Przyczynek do problematyki klauzul generalnych, „Państwo i Prawo” 1978, z. 5.

Duda A.S., Interes prawny w polskim prawie administracyjnym, Warszawa 2008.

Gersdorf M., Podstawowe dylematy zwiazane z prawem pracy w okresie transformacji ustrojowej, „Praca i Zabezpieczenie Społeczne” 2003, nr 5.

Izdebski H., Kulesza M., Administracja publiczna - zagadnienia ogólne, Warszawa 2004.

Jakimowicz W., Wyktadnia w prawie administracyjnym, Kraków 2006.

Janowicz Z., Kodeks postepowania administracyjnego. Komentarz, Warszawa 1999.

Jaśkowska M., Uznanie administracyjne a inne formy władzy dyskrecjonalnej administracji publicznej, [w:] System Prawa Administracyjnego, t. 1: Instytucje prawa administracyjnego, red. R. Hauser, Z. Niewiadomski, A. Wróbel, Warszawa 2010.

Justyński T., Nadużycie prawa w polskim prawie cywilnym, Kraków 2000.

Kalisz A., Mediacja jako forma dialogu w stosowaniu prawa, Warszawa 2016.

Kalisz A., Szot A., (Przewrotna) rola klauzul generalnych $w$ orzecznictwie europejskim. Studium „, interesu publicznego" $i$, moralności publicznej”, [w:] Konwergencja czy dywergencja kultur i systemów prawnych?, red. O. Nawrot, S. Sykuna, J. Zajadło, Warszawa 2012.

Latos-Miłkowska M., Kształt powszechnej ochrony przed wypowiedzeniem we wspótczesnym prawie pracy, „Praca i Zabezpieczenie Społeczne” 2008, nr 10.

Leszczyński L., Stosowanie generalnych klauzul odsyłających, Kraków 2001.

Leszczyński L., Tworzenie generalnych klauzul odsytających, Lublin 2000.

Leszczyński L., Maroń G., Pojęcie i treść zasad prawa i generalnych klauzul odsyłających. Uwagi porównawcze, „Annales UMCS. Sectio G” 2013, Vol. 60, nr 1.

Nowacki J., Problem blankietowości przepisów zawierających klauzule generalne, [w:] Prawo w zmieniajacym się społeczeństwie. Księga jubileuszowa Profesor Marii Boruckiej-Arctowej, red. G. Skąpska, J. Czapska, K. Daniel, K. Pałecki, Kraków 1992.

Opałek K., Problemy ,, wewnętrznej” $i$,,zewnętrznej” integracji nauk prawnych, „Krakowskie Studia Prawnicze" 1968, nr 1-2.

Pomorska A., Kontrowersje wokót przesłanek umorzenia zaległości podatkowych, [w:] Ex iniuria non oritur ius. Księga ku czci Profesora Wojciecha Łaczkowskiego, red. A. Gomułowicz, J. Małecki, Poznań 2003.

Radwański Z., Czy klauzula generalna społeczno-gospodarczego przeznaczenia prawa powinna określać treść prawa własności, [w:] ARS ET USUS. Księga pamiątkowa ku czci Sędziego Stanistawa Rudnickiego, Warszawa 2005.

Radwański Z., Zieliński M., Klauzule generalne w prawie prywatnym, [w:] System Prawa Prywatnego, t. 1: Prawo cywilne - częśś ogólna, red. M. Safjan, Warszawa 2007.

Rycak A., Powszechna ochrona trwałości stosunku pracy, Warszawa 2013.

Stelmachowski A., Klauzule generalne w prawie cywilnym, „Państwo i Prawo” 1965, z. 1. 
Szwajdler W., Ochrona prawna interesu indywidualnego w prawie budowlanym, Toruń 1993.

Wronkowska S., Ziembiński Z., Zarys teorii prawa, Poznań 2001.

Wróbel A., Interes publiczny w postępowaniu administracyjnym, [w:] Administracja publiczna u progu XXI wieku. Prace dedykowane Prof. dr. hab. Janowi Szreniawskiemu z okazji jubileuszu 45-lecia pracy naukowej, red. Z. Niewiadomski, Przemyśl 2000.

Wróblewski J., Przepisy odsyłające, „Zeszyty Naukowe Uniwersytetu Łódzkiego” 1964, z. 35.

Wróblewski J., Sadowe stosowanie prawa, Warszawa 1988.

Wypych- Żywicka A., [w:] Zarys systemu prawa pracy, t. 1: Część ogólna prawa pracy, red. K.W. Baran, Warszawa 2010.

Wyrok NSA w Warszawie z dnia 11 czerwca 1981 r., SA 820/81, LEX nr 9626.

Wyrok NSA w Warszawie z dnia 24 maja 1999 r., II SA 547/99, LEX nr 46292.

Wyrok NSA z dnia 22 kwietnia 1999 r., SA/Sz 850/98, LEX nr 36843.

Wyrok NSA z dnia 18 listopada 1999 r., II SA 1131/99, LEX nr 46696.

Wyrok NSA z dnia 5 kwietnia 2001 r., II SA 725/00, LEX nr 53476.

Wyrok NSA z dnia 26 lipca 2006 r., II OSK 1004/05, LEX nr 266429.

Wyrok NSA z dnia 7 grudnia 2011 r., I OSK 4/11, LEX nr 1149372.

Wyrok NSA z dnia 19 czerwca 2013 r., II GSK 319/12, CBOSA.

Wyrok SN z dnia 31 maja 1933 r., II K 285/33, OSN(K) 1933, z. 8, poz. 157.

Wyrok SN z dnia 18 listopada 1993 r., III ARN 49/93, LEX nr 9595.

Wyrok TK z dnia 20 marca 2006 r., K 17/05, LEX nr 182494.

Wyrok WSA w Lublinie z dnia 15 marca 2013 r., I SA/Lu 612/12, CBOSA.

Wyrok WSA w Gliwicach z dnia 7 lutego 2013 r., IV SA/Gl 211/12, LEX nr 1278056.

Wyrok WSA w Warszawie z dnia 25 czerwca 2012 r., VI SA/Wa 268/12, CBOSA.

Wyrok WSA w Warszawie z dnia 17 czerwca 2013 r., VI SA/Wa 959/13, CBOSA.

Wyrzykowski M., Pojęcie interesu społecznego w prawie administracyjnym, Warszawa 1986.

Zdyb M., Interes jednostki a interes publiczny (spoleczny). Konflikt interesów, „Annales UMCS. Sectio G" 1993, Vol. 40.

Zdyb M., Interes publiczny w orzecznictwie Trybunatu Konstytucyjnego, [w:] Pojęcie interesu w naukach prawnych, prawie stanowionym i orzecznictwie sadowym Polski i Ukrainy, red. A. Korybski, M.W. Kostyckij, L. Leszczyński, Lublin 2006.

Zdyb M., Prawny interes jednostki w sferze materialnego prawa administracyjnego. Studium teoretycznoprawne, Lublin 1991.

Zdyb M., Stelmasiak J., Zasady ogólne Kodeksu postępowania administracyjnego. Orzecznictwo Naczelnego Sadu Administracyjnego z komentarzem, Lublin 1992.

Zieliński T., Klauzule generalne w nowym porządku konstytucyjnym, „Państwo i Prawo” 1997, z. 11-12.

Zieliński T., Klauzule generalne w procesie karnym, [w:] Zasady procesu karnego wobec wyzwań wspótczesności. Księga ku czci Profesora Stanisława Waltosia, red. J. Czapska, A. Gaberle, A. Światłowski, A. Zoll, Warszawa 2000.

Ziembiński Z., Teoria prawa, Warszawa - Poznań 1973.

Żurawik A., „Interes publiczny”, ,,interes społeczny” $i$,,interes społecznie uzasadniony”, „Ruch Prawniczy, Ekonomiczny i Socjologiczny" 2003, nr 2.

\section{SUMMARY}

The publication is an attempt to present general clause as an universal construction that overcome the traditional division of legal system into branches of law not only because of its presence in every branch of law but also because of some characteristics associated with the purpose and effect of its introduction to the legal system. Detailed views of doctrine and legal practice shows similari- 
ties resulting from the axiological connotation of general clauses, their role in the processes of law application and influence of judicial practices on the understanding of these clauses. Presence of general clauses in legal system effect positively on the flexibility of law application processes and at the same time also entails difficulties associated with the need to maintain a proper balance between said flexibility and certainty and uniformity of application of the law.

Keywords: general clauses; a branch of law; legal system; application of law

\section{STRESZCZENIE}

Publikacja jest próbą przedstawienia klauzuli generalnej jako uniwersalnej konstrukcji, która przełamuje tradycyjny podział systemu prawnego do gałęzi prawa, nie tylko ze względu na swoją obecność w każdym dziale prawa, ale także z powodu pewnych cech związanych z celem i efektem jej wprowadzenia do systemu prawnego. Szczegółowe poglądy doktryny i praktyki prawniczej wykazują podobieństwa wynikające z ontologicznej konotacji klauzul generalnych, ich roli w procesach stosowania prawa i wpływu praktyki sądowej na zrozumienie poszczególnych klauzul. Obecność klauzul generalnych w systemie prawa wpływa pozytywnie na elastyczność procesów stosowania prawa, ale jednocześnie wiąże się z koniecznością utrzymania właściwej równowagi między elastycznością a pewnością i jednolitością stosowania prawa.

Słowa kluczowe: klauzule generalne; gałąź prawa; system prawa; stosowanie prawa 